\title{
Edema labial recorrente: Qual o seu diagnóstico?
}

Recurrent Lip edema: What is the diagnosis?

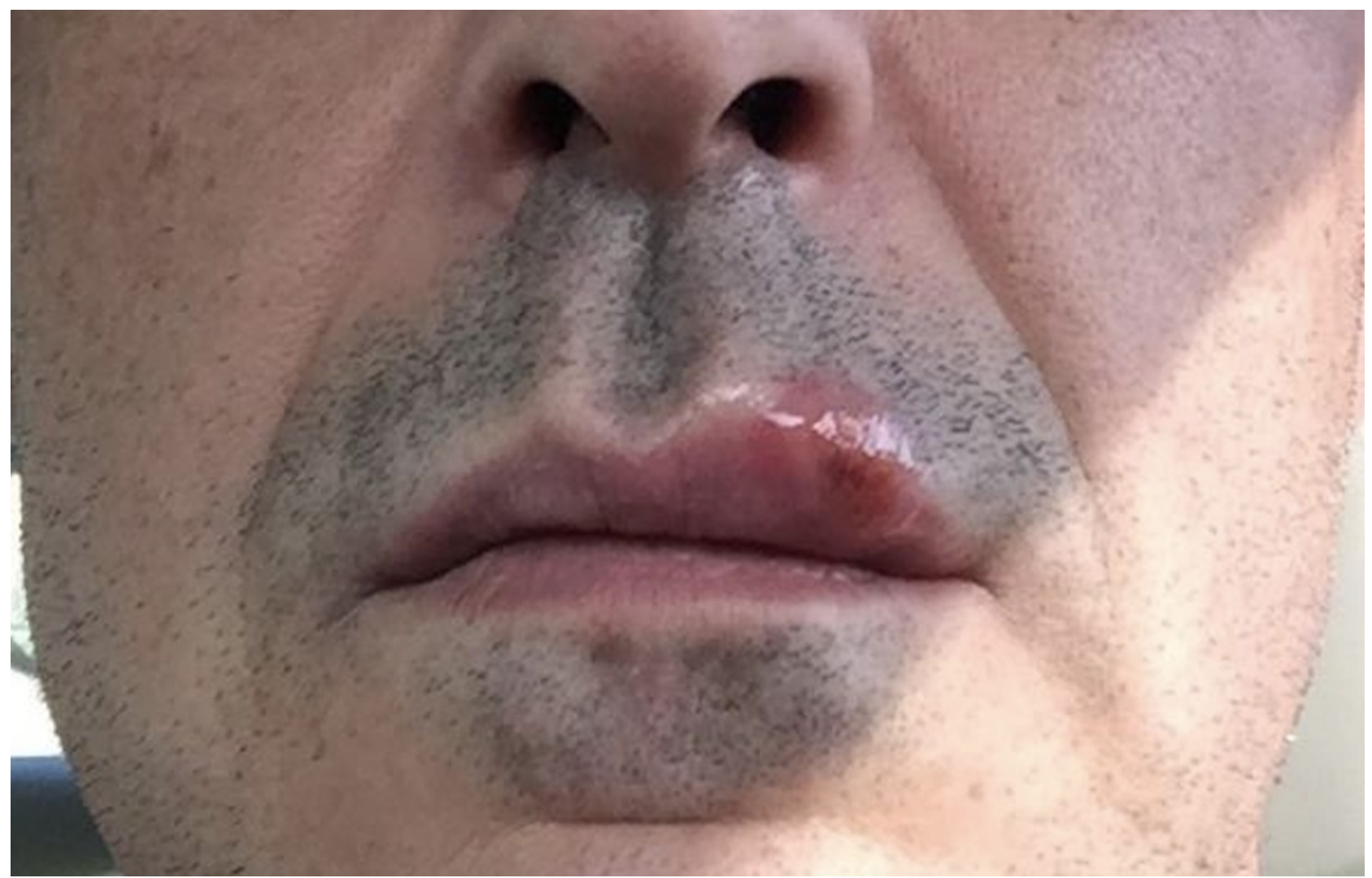

Figura I. Edema do lábio superior, eritema e lesão vesicular

Figure I. Lip edema, erithema and vesicular lesion 


\section{COMENTÁRIO}

$\mathrm{D}$ oente género masculino, 44 anos. Sem antecedentes patológicos de relevo.

Enviado à consulta de Imunoalergologia em 2018 após três episódios com frequência aproximadamente mensal de edema do lábio superior à esquerda, doloroso, não pruriginoso e com resolução espontânea em 48 horas.

Negava edema de outras regiões corporais, outros sintomas, consumo de fármacos (anti-inflamatórios ou inibidores da enzima conversora da angiotensina), picada de inseto, contacto com produtos de cosmética ou ingestão de alimentos suspeitos. Estudo analítico efetuado (hemograma, velocidade de sedimentação, proteína C reativa, função renal/hepática/tiroideia, análise sumária de urina, imunoeletroforese de proteínas, estudo do complemento e doseamento de auto-anticorpos) sem alterações de relevo.

Em 2019 novo episódio de edema do lábio superior, com aparecimento de lesão vesicular única à esquerda (Figura I). Foi efetuada zaragatoa da lesão cutânea e identificado Herpes vírus simples tipo 2 (HVS 2), tendo sido efetuado o diagnóstico de infeção herpética como causa do edema labial. Foi efetuado ensino de evicção de transmissão da infeção e iniciado tratamento com valaciclovir $500 \mathrm{mg}$ 2id durante 7 dias, com resolução dos sintomas.

Neste caso clínico importa destacar que a infeção por HVS2 é uma doença sexualmente transmissível e está mais comummente associada a úlceras genitais em mulheres, pelo que a sua manifestação sob episódios recorrentes de edema labial é incomum, mas facilmente identificada se o doente for observado aquando de recorrência de novo episódio.

Após o último episódio o doente manteve-se assintomático.

\section{COMMENT}

M ale patient with 44 years old without major pathological history.

Sent to the Immunoallergology consultation in 2018 after three episodes of monthly left upper lip's painful, non-pruritic edema with spontaneous resolution within 48 hours.

He denied edema in another body parts, other symptoms, consumption of drugs (anti-inflammatory or angiotensinconverting enzyme inhibitors), insect bite, contact with cosmetic products or ingestion of suspicious foods. The analytical study (hemogram; sedimentation rate; $C$ reactive protein; renal/hepatic/thyroid function; urine analysis; protein immunoelectrophoresis; complement study and auto-antibody evaluation) had no changes.

In 2019 the patient had a new episode of upper lip's edema with a single vesicular lesion on the left (Figure I). We have done a swab of the lesion and a Herpes simplex virus type 2 (HVS 2) was identified and the diagnosis of herpetic infection was made as the cause of lip edema. We gave advices in how to prevent infections' transmission and initiated treatment with valacyclovir $500 \mathrm{mg}$ 2id for 7 days, with resolution of symptoms.

In this clinical case is important to highlight that HVS 2 in a sexual transmitted disease and most of the times presents like genital ulcers in women, so the presentation by recurrent lip edema is uncommon and easily identified if we observe the patient along an episode.

After the last episode the patient remain asymptomatic.

\section{Conflito de interesses}

Os autores declaram que não existem conflitos de interesses.

\section{Contacto:}

Inês Machado Cunha

Serviço de Imunoalergologia, Centro Hospitalar Universitá-

rio do Porto (CHUP)

Largo do Prof. Abel Salazar

4099-00I, Porto, Portugal

E mail: inesrjmcunha@gmail.com 